\title{
PENGARUH PROFITABILITAS, NILAI PASAR, DAN MAKROEKONOMI TERHADAP HARGA SAHAM PERUSAHAAN SUB-SEKTOR PERBANKAN
}

\author{
Silvia Carolina ${ }^{1}$, Khairina Natsir ${ }^{2}$ \\ ${ }^{1}$ Program Studi Manajemen, Fakultas Ekonomi dan Bisnis, Universitas Tarumanagara \\ Email: silvia.115180094@stu.untar.ac.id \\ ${ }^{2}$ Program Studi Manajemen, Fakultas Ekonomi dan Bisnis, Universitas Tarumanagara* \\ Email: khairinan@fe.untar.ac.id \\ *Penulis Korespondensi
}

Masuk : 15-01-2022, revisi: 20-01-2022, diterima untuk diterbitkan : 25-01-2022

\begin{abstract}
ABSTRAK
Tujuan dari penelitian ini adalah untuk mengetahui 1) pengaruh profitabilitas terhadap harga saham 2) pengaruh nilai pasar terhadap harga saham 3) pengaruh inflasi terhadap harga saham 4) pengaruh tingkat suku bunga terhadap harga saham. Observasi penelitian berjumlah 180 perusahaan dari sampel sebanyak 36 perusahaan sub-sektor Perbankan yang telah terdaftar di Bursa Efek Indonesia (BEI) selama periode waktu 2016-2020. Penelitian ini menggunakan teknik purposive sampling. Metode analisis menggunakan regresi berganda dengan data berbentuk panel model random effect dan diolah menggunakan software Eviews 11. Hasil penelitian menunjukkan bahwa profitabilitas berpengaruh negatif dan signifikan terhadap harga saham, sedangkan nilai pasar berpengaruh positif dan signifikan terhadap harga saham. Berbeda dengan inflasi dan tingkat suku bunga yang secara parsial berpengaruh secara tidak signifikan dan negatif terhadap harga saham.
\end{abstract}

Kata Kunci: Harga Saham, Profitabilitas, Nilai Pasar, Makroekonomi, Inflasi, Tingkat Suku Bunga

\section{ABSTRACT}

The purpose of this study was to determine 1) the effect of profitability on stock prices 2) the effect of market value on stock prices 3) the effect of inflation on stock prices 4) the effect of interest rates on stock prices. Research observations totaled 195 companies from a sample of 39 banking sub-sector companies that were listed on the Indonesia Stock Exchange (IDX) during the 2016-2020 time period. This research uses purposive sampling technique. The analysis method uses multiple regression panel data with random effects model and is processed using Eviews 11 software. The results show that profitability has a negative and significant effect on stock prices, while market value has a positive and significant effect on stock prices. In contrast to inflation and interest rates which partially have an insignificant and negative effect on stock prices.

Keywords: Share prices, Profitability, Market value, Macroeconomic, Inflation, Interest Rates

\section{PENDAHULUAN}

\section{Latar Belakang}

Investasi merupakan suatu kegiatan dimana seorang investor/ emiten menempatkan sebagian dana yang dimilikinya saat ini pada suatu perusahaan, kemudian dengan harapan dapat memperoleh keuntungan di masa depan Tanjung, (2017). Seiring berjalannya waktu, pasar modal di Indonesia memiliki perkembangan yang sangat pesat Lisnawati \& Budiyanti, (2011). Salah satu komponen penting yang dapat membantu pertumbuhan perekonomian adalah modal. Melalui pasar modal, kelebihan dana masyarakat dapat diinvestasikan dalam suatu perusahaan/ lembaga terkait dengan harapan dapat memberikan keuntungan bagi investor melalui deviden, dan perusahaan dapat memanfaatkan dana tersebut sebagai kepentingan 
investasi tanpa harus menunggu tersedianya dana dari kegiatan operasional suatu perusahaan/ lembaga.

Harga saham adalah suatu cerminan perkembangan dari perusahaan apakah perusahaan tersebut mengalami kenaikan/penurunan. Perusahaan yang memiliki harga saham tinggi yang meningkat mencerminkan bahwa perusahaan tersebut mempunyai peluang dalam perkembangannya, sedangkan apabila harga saham rendah dan menurun maka mencerminkan bahwa perusahaan tersebut tidak mempunyai perkembangan sehingga mengalami penurunan investasi dari investor yang dapat menyebabkan terganggunya perkembangan dari perusahaan tersebut. Pernyataan oleh Fahlevi et al., (2018) bahwa salah satu faktor penilaian terhadap perusahaan dalam berinvestasi adalah melalui harga saham. Dengan meningkatnya harga saham yang terjadi karena permintaan saham yang tinggi dapat diartikan bahwa saham tersebut diminati banyak investor. Harga saham pada perusahaan sub Sektor Perbankan yang tercatat di Bursa Efek Indonesia telah mengalami pergerakan harga yang sangat berfluktuasi dari waktu ke waktu.

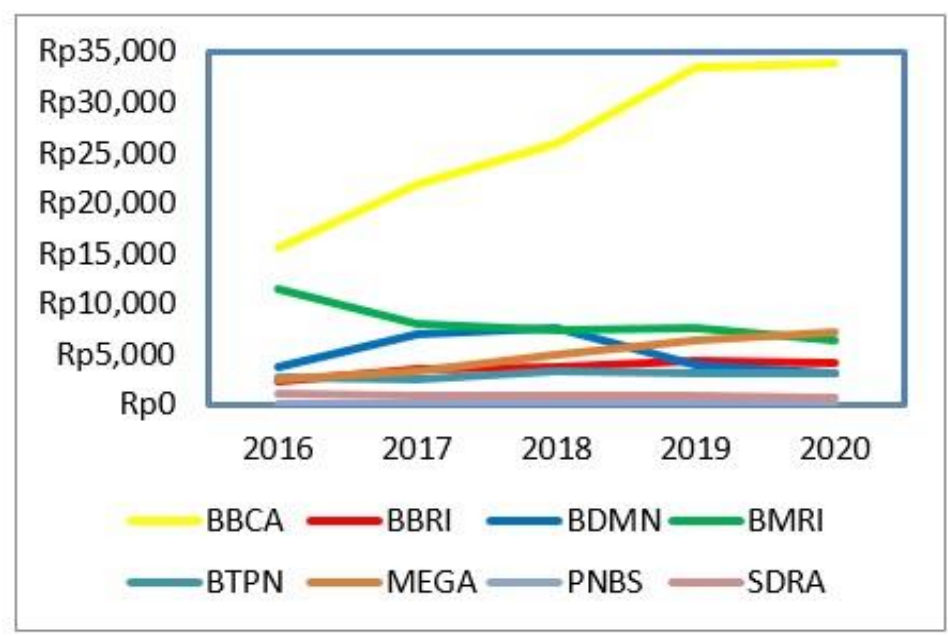

Gambar 1. Grafik Pergerakan Harga Saham beberapa Perusahaan Sub-sektor Perbankan Sumber: Data diolah

Hasan \& In'airat, (2018) menjelaskan bahwa faktor-faktor spesifik yang mempengaruhi harga saham di pasar modal pada Perusahaan Perbankan adalah faktor yang terkait dengan kinerja perusahaan dan terkait dengan kondisi ekonomi makro secara keseluruhan. Klasifikasi lain dari faktor ini merupakan faktor yang bersifat internal dan eksternal. Faktor internal adalah faktor yang terkait dengan kinerja perusahaan atau faktor mikroekonomi. Sementara faktor eksternal umumnya mencakup variabel yang mewakili kinerja ekonomi suatu Negara atau merupakan faktor ekonomi makro. Sulia, (2017) menyatakan bahwa perkembangan harga saham dalam pasar modal menjadi salah satu indikator penting bagi investor dalam mempelajari tingkah laku pasar. Investor akan melakukan dan membuat keputusan dalam berinvestasi melalui informasi-informasi yang tersedia termasuk di dalamnya faktor internal dan eksternal suatu perusahaan.

Informasi faktor internal merupakan suatu faktor yang mempengaruhi dan berasal dari internal perusahaan Perbankan diantaranya yaitu kinerja keuangan perusahaan yang dapat digunakan untuk menganalisis suatu harga saham seperti profitabilitas, nilai pasar, pertumbuhan asset dan pendapatan dividen. Lingkungan ekonomi makro menjadi lingkungan yang dapat mempengaruhi kinerja operasional dan keuangan perusahaan. Kemampuan seorang investor dalam memahami 
dan memprediksi keadaan ekonomi makro suatu Negara di masa mendatang akan sangat berguna bagi investor tersebut dalam membuat keputusan investasi terhadap harga saham yang menguntungkan. Terdapat beberapa indikator ekonomi makro yang harus diketahui investor dalam mempertimbangkan keputusan investasi diantaranya yang mempengaruhi harga saham adalah tingkat inflasi, tingkat suku bunga, nilaitukar mata uang, pertumbuhan Gross Domestic Product (GDP). Beberapa faktor ini menarik perhatian peneliti untuk dilakukan penelitian.

\section{Kajian teori}

Teori yang digunakan dalam penelitian ini adalah Signalling Theory (Teori sinyal). Signalling Theory menurut Sholichah et al., (2021) merupakan teori yang berasal dari informasi asimetri antara manajemen perusahaan dengan pemegang saham. Teori ini menyatakan bahwa manajer memiliki ketersediaan terhadap informasi manajemen perusahaan. Manajer yang memiliki keyakinan dalam prospek perusahaan yang baik, dapat menaikkan harga saham sehingga apabila investor menilai perusahaan tersebut baik, investor cenderung akan tertarik untuk berinvestasi pada perusahaan tersebut. Dari teori ini pula pemegang saham tidak sepenuhnya mengakses informasi perusahaan. Perusahaan dapat memberikan informasi yang harus dipublikasikan, namun perusahaan juga memiliki informasi yang tidak diketahui oleh pemegang saham dan menghasilkan informasi asimetri antara perusahaan dan pemegang saham. Liang \& Natsir, (2019) menyatakan bahwa Signalling theory ini adalah suatu tindakan yang diambil dari manajemen perusahaan dan membantu memberi petunjuk bagi investor mengenai cara bagaimana manajemen suatu perusahaan melihat prospek perusahaan tersebut. Teori persinyalan ini digunakan untuk memberikan sinyal kepada investor bahwa akan muncul pengembalian yang lebih tinggi di masa mendatang.

Wenny \& Hastuti (2020) Signalling Theory, merupakan teori dimana perusahaan dengan prospek yang baik memiliki tujuan untuk memaksimalkan keuntungan dari para pemangku kepentingannya. Kinerja manajemen yang baik akan memberikan hasil kinerja yang baik melalui laporan keuangan perusahaan dan perubahan posisi keuangan. Melalui kinerja manajemen ini menjadi salah satu aspek penilaian investor terhadap perusahaan. Perusahaan yang memiliki nilai kinerja yang baik akan dapat dibedakan dengan perusahaan yang memiliki kinerja yang tidak bagus / standar. Perusahaan yang memiliki k inerja baik, akan menyampaikan informasinya kepada calon investor mengenai kondisi pasarnya sehingga dapat menarik investor dan dapat meningkatkan harga saham.

Harga saham adalah harga penutupan setiap jenis saham yang ada di pasar modal selama periode pengamatan yang pergerakannya terus diamati oleh investor, selain itu harga saham merupakan salah satu indikator yang banyak digunakan oleh investor untuk mengetahui perubahan tren di pasar modal Simbolon \& Purwanto, (2018).

Menurut Christine \& Apriliana (2021), profitabilitas adalah kemampuan suatu perusahaan untuk menghasilkan keuntungan dengan menggunakan sumber daya yang dimiliki perusahaan, seperti: aset, modal atau penjualan. Nilai pasar merupakan nilai yang digunakan untuk menggambarkan nilai aset atau nilai perusahaan di pasar keuangan. Menurut Darmadji dan Fakhruddin (2012:23) dalam Faizal \& Budiarti, (2019) bahwa EPS adalah salah satu rasio nilai pasar yang memperlihatkan besarnya keuntungan yang akan diperoleh pemegang saham atau seorang investor perlembar saham dari investasi.

Inflasi adalah kenaikan harga suatu barang dan jasa yang menyebabkan daya beli turun namun biaya hidup meningkat. Inflasi dapat terjadi saat nilai mata uang merosot, dan mengakibatkan 
krisis ekonomi Subing et al., (2017). BI Rate adalah kebijakan suku bunga yang diciptakan Bank Indonesia untuk merespon tingkat inflasi dan makroekonomi lainnya Indra Widjaja, (2019). Perubahan harga saham yang terjadi pada perusahaan sub-sektor Perbankan ini disebabkan oleh beberapa faktor yaitu faktor internal perusahaan maupun eksternal (Natsir \& Bangun, 2021).

Gambar 2. Model penelitian

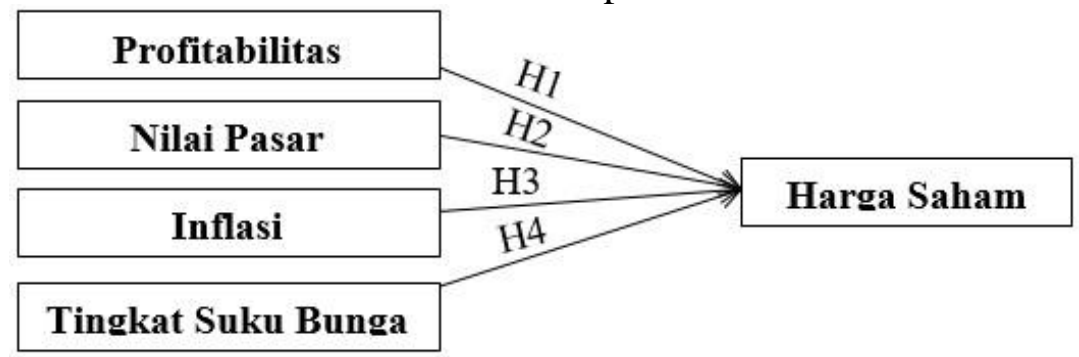

Dalam model pemikiran, maka hipotesis yang akan diuji yaitu sebagai berikut:

H1: Profitabilitas berpengaruh positif terhadap Harga Saham

H2: Nilai Pasar berpengaruh positif terhadap Harga Saham

H3: Inflasi berpengaruh negatif terhadap Harga Saham

H4: Tingkat suku bunga berpengaruh negatif terhadap Harga Saham

\section{METODE PENELITIAN}

Desain penelitian yang digunakan dalam penelitian adalah desain penelitian deskriptif kuantitatif. Subjek penelitian ini adalah Perusahaan sub-sektor Perbankan yang terdaftar di Bursa Efek Indonesia selama tahun 2016-2020. Sampel data diseleksi dengan teknik purposive sampling. Total sampel yang terpilih sebanyak 180 perusahaan selama periode 5 tahun. Objek penelitian ialah harga saham sebagai variabel dependen. Profitabilitas (ROA), nilai pasar (EPS), inflasi dan tingkat suku bunga sebagai variabel independen. Data yang dikumpulkan diolah menggunakan software Eviews 11 dan diuji dengan uji multikolinearitas, uji pemilihan model regresi, uji t dan uji koefisien determinasi dimana tingkat signifikansi yang digunakan adalah sebesar 5\%. Pengukuran variabel disarikan dalam tabel berikut ini

Tabel 1. Operasionalisasi variabel

\begin{tabular}{|c|c|c|c|c|}
\hline No & Variabel & \multicolumn{1}{|c|}{ Pengukuran } & Skala & Sumber \\
\hline 1 & Harga Saham & $\begin{array}{l}\text { Closing Price setelah 3 hari perusahaan } \\
\text { melakukan publikasi laporan keuangan (Data } \\
\text { diperoleh dari situs resmi Bursa Efek Indonesia } \\
\text { selama periode 2016-2020) }\end{array}$ & Rasio & $\begin{array}{c}\text { (www.idx.co.id) \& } \\
\text { (finance.yahoo.com) }\end{array}$ \\
\hline 2 & Profitabilitas & \multicolumn{1}{|c|}{ ROA = Net Income / Total Asset } & Rasio & $\begin{array}{c}\text { Mishkin \& Eakins, (2006) dalam } \\
\text { Deitiana \& Robin, (2016) }\end{array}$ \\
\hline 3 & Nilai Pasar & EPS = Net Income / Outstanding share & Rasio & $\begin{array}{l}\text { Darmadji \& Fakhruddin, (2012:23) } \\
\text { dalam Faizal \& Budiarti, (2019) }\end{array}$ \\
\hline 4 & Inflasi & $\begin{array}{l}\text { Perolehan data melalui situs } \\
\text { www.bps.go.id }\end{array}$ & Rasio & Rasio \\
\hline 5 & $\begin{array}{c}\text { Tingkat } \\
\text { Suku Bunga.bps.go.id }\end{array}$ & $\begin{array}{l}\text { Perolehan data melalui situs } \\
\text { www.bi.go.id }\end{array}$ \\
\hline
\end{tabular}

\section{HASIL DAN PEMBAHASAN}

\section{Uji Multikolinearitas}

Uji multikolinearitas ini dilakukan untuk memastikan apakah diantara variabel independen terdapat korelasi yang tinggi atau tidak dalam model regresi. 
Tabel 2. Hasil Uji Multikolinearitas

Sumber: Hasil Pengolahan data menggunakan Eviews 11

\begin{tabular}{|l|c|c|c|c|}
\hline & ROA & EPS & Inflasi & Tingkat Suku Bunga \\
\hline ROA & 1.0000 & 0.5151 & 0.0833 & 0.0395 \\
\hline EPS & 0.5151 & 1.0000 & 0.03001 & 0.0562 \\
\hline Inflasi & 0.0833 & 0.03001 & 1.0000 & 0.4541 \\
\hline Tingkat Suku Bunga & 0.0395 & 0.0562 & 0.4541 & 1.0000 \\
\hline
\end{tabular}

Berdasarkan hasil Uji Multikolinearitas dapat disimpulkan bahwa tidak terjadi Multikolinearitas antara variabel bebas.

\section{Uji Chow}

Uji Chow digunakan untuk memilih model yang lebih sesuai diantara Common Effect Model atau Fixed Effect Model.

Tabel 3. Hasil Uji Chow

Sumber: Hasil Pengolahan data menggunakan Eviews 11

\begin{tabular}{|l|c|c|c|}
\hline Effects Test & Statistic & d.f & Prob. \\
\hline Cross-section F & 15.698709 & $(35,140)$ & 0.0000 \\
\hline Cross-section Chi-square & 286.966575 & 35 & 0.0000 \\
\hline
\end{tabular}

Hasil Uji Chow menunjukkan bahwa probabilitas cross section- Chi Square adalah sebesar 0,00. Sehingga nilai probabilitas cross section-Chi Square kurang dari 0,05 atau < 0,05. Dapat disimpulkan bahwa model terbaik dari hasil uji Chow ini adalah Fixed Effect Model. Sehingga diharuskan untuk melanjutkan uji selanjutnya yaitu Uji Hausman.

\section{Uji Hausman}

Uji Hausman digunakan untuk memilih model yang lebih sesuai diantara Random Effect Model atau Fixed Effect Model.

Tabel 4. Hasil Uji Hausman

Sumber: Hasil Pengolahan data menggunakan Eviews 11

\begin{tabular}{|l|c|c|c|}
\hline Test Summary & Chi-Sq. Statistic & Chi-Sq. d.f & Prob. \\
\hline Cross-section random & 0.000000 & 4 & 1.0000 \\
\hline
\end{tabular}

Hasil Uji Hausman menunjukkan bahwa probabilitas cross-section random adalah sebesar 1.00. Nilai probabilitas cross-section random lebih dari 0,05 atau >0,05. Dapat disimpulkan bahwa model terbaik berdasarkan hasil uji Hausman ini adalah Random Effects Model. Sehingga diharuskan untuk melanjutkan uji selanjutnya yaitu Uji Lagrange Multiplier.

\section{Uji Lagrange Multiplier (LM)}

Uji LM digunakan untuk memilih model yang lebih sesuai diantara Random Effect Model atau Common Effect Model

Tabel 5. Hasil Uji Lagrange Multiplier

Sumber: Hasil Pengolahan data menggunakan Eviews 11

\begin{tabular}{|c|c|c|c|}
\hline & \multicolumn{3}{|c|}{ Test Hypothesis } \\
\cline { 2 - 4 } & Cross-Section & Time & Both \\
\hline Breusch-Pagan & 181.2736 & 1.221512 & 182.4951 \\
& $(0.0000)$ & $(0.2691)$ & $(0,0000)$ \\
\hline
\end{tabular}

Hasil Uji Lagrange Multiplier menunjukkan bahwa probabilitas Breusch-pagan adalah sebesar 0,00. Sehingga nilai probabilitas Breusch-pagan kurang dari 0,05 atau $<0,05$. Dapat 
disimpulkan bahwa, telah terbukti dari pengujian yang dilakukan model yang terpilih dan terbaik adalah Random Effect Model dan model ini akan digunakan untuk mengestimasi data panel dalam penelitian ini.

Tabel 6. Hasil Analisis Regresi Berganda Harga Saham

Sumber: Hasil pengolahan data menggunakan Eviews 11

\begin{tabular}{|l|c|c|c|c|}
\hline \multicolumn{1}{|c|}{ Variable } & Coefficient & Std.Error & t-Statistic & Prob. \\
\hline C & 1363.115 & 412,1620 & 3,307232 & 0,0011 \\
\hline ROA & $-7443,890$ & 3785,311 & $-1,966520$ & 0,0508 \\
\hline EPS & 6,091613 & 0,678631 & 8,976320 & 0,0000 \\
\hline Inflasi & $-8402,423$ & 9484,242 & $-0,885935$ & 0,3769 \\
\hline Tingkat Suku Bunga & $-1473,467$ & 8067,292 & $-0,182647$ & 0,8553 \\
\hline Adjusted R-Squared & \multicolumn{4}{|c|}{0,309069} \\
\hline
\end{tabular}

Berdasarkan tabel 6 maka model regresi berganda Harga Saham dapat dituliskan sebagai berikut:

\section{Harga Saham $=1363.115-7443,890 *$ ROA +6,091613 $*$ EPS-8402,423*INF-1473,467*TSB}

Apabila Return on Assets (ROA), Earning per Share (EPS), Inflasi dan tingkat suku bunga sebesar 0 (nilai konstan), maka harga saham yang dihasilkan adalah 1363.115. Jika terjadi kenaikan dari Return on Asset (ROA) sebanyak 1 dan variabel lainnya dianggap memiliki nilai konstan, maka Return on Assets (ROA) akan menurun sebanyak 7443,890 satuan. Jika terjadi kenaikan dari Earning Per Share (EPS) sebanyak 1 dan variabel lainnya dianggap memiliki nilai konstan, maka Earning per Share (EPS) akan meningkat sebesar 6,091613 satuan. Jika terjadi kenaikan dari inflasi sebanyak 1 dan variabel lainnya dianggap memiliki nilai konstan, maka inflasi akan menurun sebanyak 8402,423satuan. Dan apabila terjadi kenaikan sebanyak 1 dan variabel lainnya dianggap memiliki nilai konstan, maka tingkat suku bunga akan menurun sebanyak 1473,467 satuan.

Berdasarkan dari uji-t bahwa diperoleh nilai probabilitas dari variabel Return on Assets adalah sebesar 0,0508 yang artinya sama dengan 0,05 atau $=0,05$, ini menunjukkan bahwa terdapat pengaruh yang signifikan dari ROA terhadap harga saham. Nilai probabilitas dari variabel Earning Per Share adalah sebesar 0,0000 yang artinya lebih kecil dari 0,05 atau < 0,05, sehingga ini menunjukkan bahwa terdapat pengaruh yang signifikan dari variabel EPS terhadap harga saham. Nilai probabilitas dari variabel Inflasi adalah 0,3769 yang artinya lebih besar dari 0,05 atau >0,05, sehingga ini menunjukkan bahwa terdapat pengaruh yang tidak signifikan dari variabel inflasi. Nilai probabilitas dari variabel tingkat suku bunga adalah 0,8553 yang artinya lebih besar dari 0,05 atau $>0,05$, ini menunjukkan bahwa terdapat pengaruh yang tidak signifikan dari variabel tingkat suku bunga terhadap harga saham pada Perusahaan sub-sektor Perbankan yang terdaftar di BEI selama periode tahun 2016-2020.

Hasil uji koefisien determinasi yang ditunjukkan oleh Adjusted R-Squared adalah sebesar 0,31 atau 31\%. Dapat diartikan bahwa harga saham (variabel terikat) dapat dijelaskan oleh variasi variabel independen yakni profitabilitas (ROA), nilai pasar (EPS), inflasi, dantingkat suku bunga dijelaskan sebesar 0,31 atau 31\%. Sedangkan 69\% sisanya akan dan dapat dijelaskan oleh variabel independen lainnya di luar dari penelitian ini. 


\section{Diskusi}

Hasil penelitian terdahulu dilakukan oleh Satryo et al. (2017) dan Purnamawati, (2016) bahwa Profitabilitas berpengaruh positif signifikan terhadap harga saham. Sedangkan, hasil penelitian oleh Bhattarai, (2018) menunjukkan hasil bahwa Profitabilitas berpengaruh negatif signifikan terhadap harga saham, sedangkan penelitian dari Utami \& Darmawan, (2019) menunjukkan Profitabilitas tidak berpengaruh signifikan terhadap harga saham. Hasil penelitian terdahulu oleh Astuty (2017) menunjukkan Nilai pasar mempengaruhi harga saham secara signifikan. Didukung oleh hasil penelitian Ariesa et al. (2020) yang menunjukkan bahwa Nilai pasar merupakan variabel yang mempengaruhi harga saham secara positif signifikan. Berbeda dengan hasil penelitian Faizal \& Budiarti, (2019) menunjukkan bahwa Nilai pasar berpengaruh negatif namun tidak signifikan terhadap harga saham.

Inflasi dari hasil penelitian terdahulu oleh Yunita \& Robiyanto, (2018) menunjukkan inflasi tidak berpengaruh secara signifikan terhadap harga saham. Penelitian lain oleh Silva, (2016) menunjukkan bahwa inflasi memiliki pengaruh negatif dan signifikan terhadap harga saham. Hasil penelitian terdahulu yang ditunjukkan oleh Indra Widjaja (2019) dan Kurniawan \& Yuniati, (2019) bahwa suku bunga memiliki pengaruh negatif signifikan terhadap harga saham. Berbeda dengan hasil penelitian oleh Anggraeni et al., (2020) yang menunjukkan bahwa tingkat suku bunga tidak berpengaruh signifikan terhadap harga saham.

Hasil pembahasan dari penelitian ini menghasilkan hasil yang berbeda-beda dan beragam dari setiap faktor. Faktor pertama profitabilitas (ROA) ternyata berpengaruh negatif dan signifikan terhadap harga saham. Hasil penelitian ini didukung oleh penelitian terdahulu yang dilakukan oleh Ivan, (2018) yang menjelaskan bahwa pemanfaatan dan pengelolaan aset yang tinggi namun tidak efektif akan mempengaruhi kegiatan operasional perusahaan dan menyebabkan merosotnya laba perusahaan, sehingga alokasi aset perusahaan yang tidak baik dapat menurunkan minat para investor karena mengakibatkan kinerja aset yang buruk. Kinerja dan produktivitas aset pada perusahaan perbankan tidak dapat mempengaruhi perolehan keuntungan terhadap harga saham, dikarenakan faktor lain lebih mempengaruhi harga saham.

Faktor selanjutnya yaitu nilai pasar (EPS) yang menunjukkan pengaruh positif dan signifikan terhadap harga saham, hasil analisis ini sejalan dengan penelitian terdahulu oleh Ariesa et al., (2020) dan Astuty, (2017). Rasio nilai pasar yang tinggi dan besar menunjukkan bahwa pertumbuhan nilai pasar perusahaan sangat baik, sehingga semakin tinggi dan meningkat nilai pasar maka dapat mempengaruhi kenaikan bagi harga saham. Jika EPS dan nilai pasar perusahaan memiliki nilai tinggi maka dapat memberikan informasi dan dapat menarik minat investor dalam berinvestasi pada harga saham perusahaan Perbankan. Nilai pasar yang baik digambarkan dari laba lembar per saham suatu perusahaan, sehingga ini menunjukkan bahwa perusahaan dapat memberikan kesejahteraan yang maksimum bagi pemegang saham. Dengan ini para investor akan terdorong untuk melakukan investasi pada perusahaan perbankan dan dapat menjadikan EPS sebagai salah satu faktor dalam menilai harga saham.

Hasil analisis selanjutnya ialah bahwa inflasi memiliki pengaruh yang negatif dan tidak signifikan terhadap Harga saham yang sejalan dengan penelitian terdahulu oleh Gunawan \& Firdausy, (2017). Hal ini dikarenakan penggunaan utama inflasi adalah sebagai indikator fundamental ekonomi dalam mencerminkan tingkat PDB. Inflasi yang terjadi juga dapat menyebabkan biaya yang relatif tinggi dibanding pendapatan perusahaan, sehingga perusahaan mengalami penurunan laba, hal ini membuat investor menjadi tidak berminatuntuk berinvestasi pada perusahaan tersebut, sehingga akibatnya harga saham 
cenderung menurun. Inflasi yang meningkat memang akan memberikan isyarat negatif terhadap harga saham. Inflasi yang terjadi pada periode 2016-2020 menunjukkan adanya fluktuasi yang tidak stabil dengan alasan lain, ini tidak berdampak secara langsung dalam mempengaruhi harga saham.

Hasil penelitian selanjutnya yaitu tingkat suku bunga menunjukkan pengaruh negatif dan tidak signifikan terhadap Harga saham. Tingkat suku bunga tidak menjadi indikator yang dapat mempengaruhi harga saham secara langsung. Tingkat suku bunga yang tinggi dapat menyebabkan investor berpikir untuk bergantung dengan pengembalian tingkat suku bunga, sehingga disimpulkan bahwa tingkat suku bunga yang tinggi justru akan menekan harga saham mengakibatkan investor beralih untuk berinvestasi pada tabungan dan deposito.

\section{KESIMPULAN DAN SARAN}

Hasil pertama menujukkan hasil yang berbeda dengan hipotesis. Maka hipotesis pertama ditolak. Artinya Return on Assets berpengaruh negatif dan signifikan terhadap Harga Saham pada perusahaan sub-sektor Perbankan. Pada penelitian selanjutnya penggunaan variabel ini dapat diganti dan atau ditambahkan dengan variabel lainnya yaitu Return on Equity, sehingga diharapkan dapat memberikan hasil penelitian yang lebih mendekati hipotesis yang dijabarkan.

Hasil kedua yang menunjukkan hasil yang sama dengan hipotesis. Sehingga hipotesis yang kedua diterima. Pengaruh dari Earning per share menunjukkan pengaruh yang positif dan signifikan terhadap Harga Saham Perusahaan sub-sektor Perbankan. Dengan hasil dan hipotesis yang sama, maka para investor harus berfokus terhadap EPS perusahaan dalam menjadikan penentu keputusan dalam berinvestasi dan menilai harga saham suatu perusahaan

Hasil ketiga dan keempat menunjukkan hasil hipotesis yang sama dengan penelitian. Sehingga hipotesis ketiga dan keempat diterima. Dikarenakan pengaruh dari inflasi dan tingkat suku bunga memiliki pengaruh yang negatif namun tidak signifikan terhadap Harga saham perusahaan sub-sektor Perbankan yang terdaftar di Bursa Efek Indonesia selama periode tahun 2016-2020, maka diharapkan pada penelitian selanjutnya agar dapat menambahkan variabel penelitian, menambahkan periode waktu, untuk memberikan gambaran keadaan yang sebenarnya. Meskipun hasil menunjukkan terdapat 3 variabel yang berpengaruh tidak signifikan, namun disarankan untuk tetap memperhatikan ketiga variabel ini, karena kemungkinan variabel terkait dapat berpengaruh dan memberikan hasil signifikan pada penelitian selanjutnya di kondisi ekonomi dan waktu di masa depan

\section{REFERENSI}

Anggraeni, D. L., Suharti, T., \& Yudhawati, D. (2020). Pengaruh Inflasi Dan Suku Bunga Terhadap Harga Saham Pada Perusahaan Sektor Perbankan. Manager: Jurnal Ilmu Manajemen, 2(3), 343. https://doi.org/10.32832/manager.v2i3.3710

Ariesa, Y., Tommy, T., Utami, J., Maharidha, I., Siahaan, N. C., \& Nainggolan, N. B. (2020). The Effect of Current Ratio (CR), Firm Size (FS), Return on Equity (ROE), and EarningPer Share (EPS) on the Stock Prices of Manufacturing Companies listed in Indonesia Stock Exchange in the 2014-2018 Period. Budapest International Research and Critics Institute (BIRCI-Journal): Humanities and Social Sciences, 3(4), 2759-2773. https://doi.org/10.33258/birci.v3i4.1286 
Astuty, P. (2017). The influence of fundamental factors and systematic risk to stock prices on companies listed in the Indonesian stock exchange. European Research Studies Journal, 20(4), 230-240. https://doi.org/10.35808/ersj/830

Bhattarai, B. P. (2018). The Firm Specific and Macroeconomic Variables Effects on Share Prices of Nepalese Commercial Banks and Insurance Companies. Review of Integrative Business and Economics Research, 7(3), 1-11.

Christine, D., \& Apriliana, T. (2021). The Influence of Profitability, Technical Analysis Education and Liquidity Toward Stock Price: An Empirical Study on Banking Sector in Indonesia. Review of International Geographical Education, 11(1), 583-588. https://doi.org/10.48047/rigeo.11.1.42

Deitiana, T., \& Robin, M. (2016). the Effect of Firm Size, Profitability, Tangibility, Non- Debt Tax Shield and Growth to Capital Structure on Banking Firms Listed in Indonesia Stock Exchange From 2007-2012. South East Asia Journal of Contemporary Business, Economics and Law, 10(1), 37-44.

Fahlevi, R. R., Asmapane, S., \& Oktavianti, B. (2018). Pengaruh kinerja keuangan terhadap harga saham pada perusahaan perbankan yang terdaftar di bursa efek indonesia The effect of financial performance on stock prices on banking companies listed on the stock exchange of Indonesia. Akuntabel, 15(1), 39-48.

Faizal, \& Budiarti, A. (2019). Pengaruh profitabilitas, nilai pasar, dan inflasi terhadap harga saham. Jurnal Ilmu Dan Riset Manajemen, 8(7).

Gunawan, C., \& Firdausy, C. M. (2017). Pengaruh PDB, Inflasi, Tingkat Suku Bunga dan Nilai Tukar Rupiah terhadap Indeks Harga Saham JakProp yang terdaftar di Bursa Efek Indonesia. Jurnal Manajemen Bisnis Dan Kewirausahaan, 1, 100-107.

Hasan, M., \& In'airat, S. (2018). The effect of internal and external factors on stock market prices-evidence from Saudi Arabia. The Business and Management Review, 9(3), 9-10.

Indra Widjaja, H. D. (2019). Pengaruh Bi Rate, Inflasi, Fluktuatif Kurs Dan Volume Perdagangan Saham Terhadap Indeks Harga Saham Gabungan Periode 2009-2017. Jurnal Manajemen Bisnis Dan Kewirausahaan, 2(4), 25-33. https://doi.org/10.24912/jmbk.v2i4.4860

Ivan. (2018). Analisis Pengaruh Faktor-Faktor Fundamental Terhadap Harga Saham (Studi Empiris Pada Perusahaan Manufaktur Yang Terdaftar di Bursa Efek Indonesia Periode 2012-2015). Jurnal Muara Ilmu Ekonomi Dan Bisnis, 2(1), 254. https://doi.org/10.24912/jmieb.v2i1.756

Kurniawan, A., \& Yuniati, T. (2019). Pengaruh Inflasi, Suku Bunga dan NilaiTukar terhadap Harga Saham Perusahaan Perbankan. Jurnal Ilmu Dan Riset Manajemen, 8(1), 1-16.

Liang, I., \& Natsir, K. (2019). Pengaruh Profitabilitas, Likuiditas, Dan Ukuran Perusahaan Terhadap Struktur Modal. Jurnal Manajerial Dan Kewirausahaan, 1(3), 481-480. https://doi.org/10.52421/fintax.v1i1.130

Lisnawati, \& Budiyanti, E. (2011). Perkembangan Pasar Modal Dan Pertumbuhan EkonomiDi Indonesia: Analisis Vector Autoregressions (VAR). Jurnal Ekonomi \& Kebijakan Publik, 2(2), 707-728.

Natsir, K., \& Bangun, N. (2021). Pengaruh Inflasi, Good Corporate Governance, Dan Investment Opportunity Set Terhadap Kebijakan Dividen. Jurnal Ekonomi Dan Pembangunan, 12(1), 57-70. https://doi.org/10.22373/jep.v12i1.147

Purnamawati, I. G. A. (2016). (Study of the Manufacturing Sector in Indonesia Stock Exchange). International Hournal of Business, Economics and Law, 9(1), 10-16.

Satryo, A. G., Rokhmania, N. A., \& Diptyana, P. (2017). The influence of profitability ratio, market ratio, and solvency ratio on the share prices of companies listed on LQ 45 Index. The Indonesian Accounting Review, 6(1), 55. https://doi.org/10.14414/tiar.v6i1.853 
Sholichah, F., Asfiah, N., Ambarwati, T., Widagdo, B., Ulfa, M., \& Jihadi, M. (2021). The Effects of Profitability and Solvability on Stock Prices: Empirical Evidence from Indonesia. Journal of Asian Finance, Economics and Business, 8(3), 885-894. https://doi.org/10.13106/jafeb.2021.vol8.no3.0885

Silva, N. L. C. (2016). Effect Of Inflation On Stock Prices: Evidence From Sri Lanka. International Journal of Scientific \& Engineering Research, 7(4), 1278-1279.

Simbolon, L., \& Purwanto. (2018). The Influence of Macroeconomic Factors on Stock Price: The Case of Real Estate and Property Companies. UK: Emerald Publishing Limited.

Subing, H. J. T., Wedi Rusmawan Kusumah, R., \& Gusni. (2017). An empirical analysis of internal and external factors of stock pricing: Evidence from Indonesia. Problems and Perspectives in Management, 15(4), 178-187. https://doi.org/10.21511/ppm.15(41). 2017.02

Sulia. (2017). Analisis Faktor-Faktor Yang Mempengaruhi Audit Delay Pada Perusahaan Lq45 Yang Terdaftar Di Bursa Efek Indonesia. Jurnal Wira Ekonomi Mikroskil, 7(2). https://doi.org/10.20961/jab.v14i1.149

Tanjung, G. (2017). Factors that Affect Stock Pricing in Indonesia Stock Exchange. September 2016.

Utami, M. R., \& Darmawan, A. (2019). Effect of DER, ROA, ROE, EPS and MVA on Stock Prices in Sharia Indonesian Stock Index. Journal of Applied Accounting and Taxation, 4(1), 15-22. https://doi.org/10.30871/jaat.v4i1.1195

Wenny, \& Hastuti, R. T. (2020). Faktor yang Mempengaruhi Harga Saham pada Indeks Lq45 yang terdaftar dalam BEI. Jurnal Multiparadigma Akuntansi Tarumanagara, 2(1), 317326.

Yunita, Y., \& Robiyanto, R. (2018). the Influence of Inflation Rate, Bi Rate, and Exchange Rate Changes To the Financial Sector Stock Price Index Return in the Indonesian Stock Market. Jurnal Manajemen Dan Kewirausahaan, 20(2), 80-86. https://doi.org/10.9744/jmk.20.2.80-86 